\title{
RUBÉN DARÍO I SANTIAGO RUSIÑOL: POLÍTICA I PERIODISME LITERARI EN LA BARCELONA MODERNISTA
}

\author{
ANTONI MARTÍ MONTERDE
}

\begin{abstract}
This essay aims to review literary journalism both in Catalan and American Modernism, specifically through the works of Rubén Darío and Santiago Rusiñol, in order to achieve a better understanding of the contemporary idea of literary Cosmopolitanism. The framework to support this analysis goes from Desde el Molino, written by Rusiñol in Paris between 1890 and 1894, to the chapter devoted to Barcelona by Darío in España contemporánea, written between 1899 and 1901. Reading these works as journalistic reflections on modernity and cosmopolitanism also calls for considering the reactions against them, both from a political and aesthetic perspective, by some prominent Spanish writers. In this respect, the fin-de-siècle Catalan and American literature may be a key aspect concerning a redefinition of the cultural history of literary Cosmopolitanism.
\end{abstract}

$\mathrm{L}$ 'any 1898, Rubén Darío, que vivia a l’Argentina des de 1983, va acceptar un encàrrec periodístic del diari La Nación de Buenos Aires: unes cròniques de viatge a Espanya, que apareixeran entre el 3 de desembre de 1898 i el 7 d'abril de 1900. L'objecte d'aquell encàrrec, que ell mateix havia propiciat, era molt clar: captar l'ambient a l'Espanya que acabava de perdre Cuba. El resultat és un dels llibres més cèlebres — per bé que no dels més celebrats en el seu moment- de l'escriptor nicaragüenc: España contemporánea. Poc més tard, Santiago Rusiñol edita una segona edició d'un recull d'articles també publicats originàriament a la premsa —en aquest cas barcelonina, La Vanguardia, en 1890. Es tracta del també força conegut Desde el Molino, recull de les cròniques de la seva estada a París.

Són moltes les coses que tenen en comú aquests dos títols, a banda de compartir el gènere de la crònica de viatge, com també són moltes les afinitats entre tots dos autors, capdavanters dels respectius modernismes, amb Joan Maragall al costat, en el cas català. Però cal aturar-se en una coincidència molt significativa entre tots dos llibres, una dada de gran importància amagada a la vista de tothom, en les seves cobertes. Publicat significativament no a Buenos Aires, ni a Madrid, sinó a París, en 1901, el llibre de Darío apareix a Garnier Hermanos, és a dir, la col·lecció en castellà de l'editorial parisenca Garnier Frères, on també s'edita, en 1903, la segona edició del llibre de Rusiñol, com també la tercera, corregida i augmentada amb un altre recull d'articles literaris, Impresiones de arte. Tots dos llibres apareixen 
amb la seva característica tipografia daurada sobre fons de color bordeus, que amb el pas d'un segle ha envellit cap al marró brut però en què encara resisteixen uns elegants filets Bodoni, igualment daurats, emmarcant discretament el conjunt. La sèrie en castellà de l'editorial Garnier era dirigida per Enrique Gómez Carrillo, un escriptor originari de Guatemala que havia participat en els anys immediatament anteriors en revistes com Cosmópolis de Pedro Emilio Coll i Luis Manuel Urbaneja Achelpohl, de Caracas, i que a partir d'aquella experiència d'introducció de la poesia simbolista francesa en Amèrica, estableix un lligam gairebé definitiu amb París, on s'installa i on s'integra plenament en els darrers moviments de la vida bohèmia, en l'entorn del Quartier Latin. Les activitats de Gómez Carrillo, inicialment centrades en els escriptors americans, aniran ampliant-se més tard, a partir de la dècada dels anys 10 , en què sovinteja també els cercles de Madrid, a alguns escriptors espanyols afins més que al modernisme, a la bohèmia. En el moment en què Darío i Rusiñol publiquen els seus respectius llibres a Garnier, aquesta editorial s'ha convertit en una alternativa - per no dir en una amenaça- per les editorials espanyoles, que no saben fer front als tiratges i difusió del segell parisenc (Fernández, "La editorial Garnier...”). És cert que el llibre de Rusiñol havia aparegut per primer cop, amb il-lustracions de Ramon Casas, a Tipografia L'Avenç en 1894; i que en 1898 havia aparegut un llibre, en aquesta ocasió en català, Fulls de la vida, que en el capítol titulat "Una casa a París" partia dels mateixos escenaris i anècdotes. També és cert que l'editorial de la revista madrilenya La Lectura va publicar una edició del llibre del nicaragüenc el mateix any que havia aparegut l'edició francesa. Però aquesta condició de llibres publicats amb peu d'impremta a París ha de ser considerada en la seva importància. La significació d'aquesta dada és molt clara: París, tant per Buenos Aires com per Barcelona, és una ciutat de referència — en aquest cas, també de referència bibliogràfica, de punt a partir del qual la circulació de les propostes estètiques es posa d'acord amb la modernitat editorial, que en el cas de Barcelona ja s'havia començat a donar, i que experimentarà, gràcies a aquesta relació estable amb París, un impuls definitiu.

En aquest sentit, cal subratllar, com ho fa Joan Ramon Resina (La vocació de modernitat 19-71) que els processos pels quals Barcelona s'incorpora a aquesta modernitat són molt ràpids, vinculats a una profunda transformació de la burgesia barcelonina que determinarà també uns canvis profund en les dinàmiques culturals urbanes ja des de la dècada des anys 60, canvis pels quals París resulta poc més tard un referent inexcusable. I, de la mà d'aquesta consciència de modernitat, de pensament d'avançada que s'escampa per tots els ordres de la vida social i artística, cal situar explícitament el modernisme, que tindria a Barcelona un dels centres d'irradiació més importants, decisiu també per al seu desenvolupament americà, precisament en virtut de la seva coincidència a París. Com assenyala lúcidament Vicente Cacho: 
El modernismo catalán es anterior en el tiempo al del resto de España. Este dato no tendría un significado especial —al fin y al cabo, quizá sea aún más antiguo el modernismo castellano-parlante del Caribe- de no haberse convertido en un factor estratégico de primordial importancia para la afirmación del nacionalismo cultural. La independización de Cataluña - en el plano del pensamiento, no de la política - es el hecho de más relevancia, desde el punto de vista de la historia intelectual, en el fin de siglo español. (...) Madrid y Barcelona se constituyen en capitales autónomas de cultura dentro de un universo latino cuya metrópoli, todavía indiscutida, era París. (Cacho Viu, El nacionalismo catalán 49)

Com pot apreciar-se en la lectura del procés modernista de Vicente Cacho, des del punt de vista intel-lectual-literari, la independència de Catalunya estaria estretament lligada a una cronologia en què el Modernisme català pot ser vist com l'avançada d'uns processos d'abast iberoamericà en què la dimensió ibèrica, en aquest moment, només seria representada per Catalunya; la qual cosa, com veurem, Rubén Darío va saber apreciar molt nítidament tant a través de la seva estada a Barcelona com amb la lectura de les revistes modernistes catalanes i, molt especialment, la lectura de Santiago Rusiñol. Al costat de la problemàtica de la cronologia del modernisme - no cal subscriure la proposada per Cacho per considerar-la interessant-, cal situar el fet, decisiu, que és en relació a les respectives posicions dels modernistes catalans i americans a París que el moviment modernista intensifica les transformacions en el pla literari, artístic i intel·lectual iniciades poc abans, transformacions que tenen conseqüències també en el pla polític, i en aquest darrer punt també la relació entre Darío i Rusiñol resulta clau.

\section{DARÍO I RUSIÑOL, PERIODISTES FRANCESOS}

Encara que el seu perfil sigui eminentment poètic, cal tenir present que dues terceres parts de l'obra de Rubén Darío són proses diverses que es publiquen originàriament a la premsa periòdica; i un percentatge semblant de l'obra de Santiago Rusiñol també té en el periodisme el seu origen. Aquesta és una dada de gran importància, tan quantitativament com qualitativament: són articles, cròniques literàries, ressenyes i retrats el algun cas, que donen compte de la formació mateixa de les seves respectives mirades en tant que mirada moderna. Tanmateix, com ha assenyalat Ángel Rama en la seva lúcida revalorització del paper del periodisme en Darío i en el conjunt del modernisme americà, en aquell moment, hi ha dos models de periodisme en pugna: el francès, dotat de generosos espais editorials i d'opinió, i l'estadounidenc, més donat a la notícia breu, llampant, informativa. Inclinat inicialment pel model francès, en el nord-americà trobarà, com ha assenyalat Rama, no poques afinitats, ja que les: 
tendencias estilísticas epocales son: novedad, atracción, velocidad, shock, rareza, intensidad, sensación. Las mismas que reencontraremos en el arte modernista. La búsqueda de lo insólito, los acercamientos bruscos de elementos disímiles, la renovación permanente, las audacias temáticas, el registro de los matices, la mezcla de las sensaciones, la interpenetración de distintas disciplinas, el constante, desesperado afán de lo original, son a su vez rasgos que pertenecen al nuevo mercado, y, simultáneamente, formes de penetrarlo y dominarlo.

Esas formas estuvieron primero en el periodismo que en la poesía, y allí estuvieron primero los temas que ella cultivó. (Rama, Rubén Darío y el modernismo 76-77)

El paper de la premsa en l'articulació narrativa de la ciutadania lliga, en el model francès, amb la figura del chroniqueur, una figura que havia transformat l'article de costums o de choses vues en una mirada poètica als diversos fets de la vida quotidiana de la ciutat que no entrarien dins la secció "faits divers" d'un quotidien. Es tractava, a través de l'atenció que es fixa en l'insignificant, en el detall gairebé imperceptible recollit força sovint amb un llenguatge simbolista i impressionista, de captar l'ànima de la vida urbana i traslladar-la a les planes del periòdic, en un moment en què, sobretot a partir del nomenament en 1853 del baró Haussmann com a Préfet - i artiste démolisseur-, la ciutat canvia a un ritme que desborda tota mètrica. No és un altre l'origen dels Petits poèmes en prose de Charles Baudelaire, dels Croquis Parisiens de Joris-Karl Huysmans, o dels Esquisses de Henri de Regnier sense obviar l'oblidadís periodisme d'Edgar Alan Poe; es tracta d'una línia que s'ha de concebre com una tradició, sòlida i discontínua alhora, que arribarà, epilogalment o epigonalment, fins a Léon-Paul Fargue.

A la fi de segle ens trobem encara un moment en què és la figura lletrada, gairebé poètica, la que aporta al periodisme unes pàgines que el canviaran per sempre, $\mathrm{i}$ que transformaran també per sempre l'“ànima urbana”. La literatura espanyola no havia conegut la continuïtat amb la tradició de l'article de costums francès, que Mariano José de Larra, - ben considerat i citat per modernistes catalans com Joan Maragall, i a qui Darío també elogia-, va portar al seu cim en llengua castellana, i no va veure la represa d'aquesta tradició fins la renovació protagonitzada per la intel-ligent síntesi de realisme $\mathrm{i}$ avantguardisme, una mica vuitcentista, dels elucidarios madrilenys de Ramón Gómez de la Serna. La renovació de la crònica periodística en llengua castellana ve d'Amèrica: propiciada en part per Sarmiento, es desenvolupa plenament amb José Martí i després amb Darío; són autors, en lúcida síntesi de Rama, que "Dignificaron el género. Sintiéndose atacados por la aparición del "reporter" que invadía las redacciones, supieron luchar en su misma línea apelando a un don propio, insustituible, la escritura”, (Rama, Rubén Darío y el modernismo 75) que viuen en temps real un procés - que en el cas francès s'havia donat en els anys 20 i 30 del segle XIX - en què les figures lletrades deixen de coincidir inexorablement amb les acadèmiques o polítiques, s'autonomitzen, es 
relacionen amb l'acadèmia i amb la política amb formes d'intervenció en l'espai públic específicament literàries, atenen per igual als nous mites burgesos i populars en la ciutat modernitzada, i creen per a ella nous mites urbans.

Però a finals del segle XIX i començaments del XX la textura periodística d'aquesta mena d'escrits ja s'ha fet molt més nítida, i reclama el seu reconeixement explícit. Aquest reconeixement el farà Darío en "El periodista y su mérito literario", recollit en Impresiones y sensaciones, que serveix de síntesi de la seva percepció de la qüestió. Darío reivindica que, "Muy hermosos, muy útiles y muy valiosos volúmenes podrían formarse con entresacar de las colecciones de los periódicos la producción, escogida y selecta, de muchos, considerados como simples periodistas"; aquesta argumentació serveix, pràcticament, per a caracteritzar una part de la seva obra, oculta sota els nenúfars amb que sempre s'han volgut perfumar els seus llibres:

Hoy, y siempre, un periodista y un escritor se han de confundir. La mayor parte de los fragmentarios son periodistas. Montaigne y de Maistre son periodistas, en un amplio sentido de la palabra. Todos los observadores y comentadores de la vida han sido periodistas. Ahora, si os referís simplemente a la parte mecánica del oficio moderno, quedaríamos en que tan solo merecerían el nombre de periodistas los reporters comerciales, los de los sucesos diarios; y hasta éstos pueden ser muy bien escritores que hagan sobre un asunto árido una página interesante, con su gracia de estilo y su buen por qué de filosofía. Hay editoriales políticos escritos por hombres de reflexión y de vuelo, que son verdaderos capítulos de libros fundamentales, y eso pasa. Hay crónicas, descripciones de fiesta o ceremoniales escritas por reporters que son artistas, las cuales, aisladamente, tendrían cabida en obras antológicas, y eso pasa. El periodista que escribe con amor lo que escribe, no es sino un escritor como otro cualquiera.

Solamente merece la indiferencia y el olvido aquel que, premeditadamente, se propone escribir, para el instante, palabras sin lastre e ideas sin sangre. (Rubén Darío, "El periodista y su mérito literario" $880-81$ )

Per tant, la consideració d'una tradició literària per a aquest periodisme ja és un efecte de la manera de mirar la realitat, que busca els seus precursors en l'assaig francès - no en l'anglès, com hauria estat més lògic si pensem en Joseph Addison i Richard Steele - com a continuació lògica de la tradició poètica que sustenta la seva modernitat.

La condició de relat de viatge en aquests escrits del periodisme literari de Darío no sol ser apreciada en la seva importància, malgrat la consciència d'aquesta textura que exhibeix cada pàgina. La capacitat per veure l'altre, els altres, que desplega Darío en Espanya contemporánea resultaria així no tan sols un tret de reconeixement estètic, sinó una capacitat intrínsecament desenvolupada en l'evolució d'un gènere literari que, amb José Martí i Rubén Darío i amb 
Santiago Rusiñol, farà en només dues dècades unes aportacions decisives per a les generacions posteriors d'escriptors en viatge. I, de fet, aquest és un tret que també té conseqüències en la percepció que Darío té, a Espanya, de les possibilitats de regeneració. Aquesta possibilitat solament queda inequívocament reconeguda en la crònica datada el 10 d'abril "La Pardo Bazán en París" (Darío, España contemporánea 125-29) — precisament en París-, que sembla atorgar a Espanya alguna capacitat de reacció, no necessàriament coincident en allò estètic amb els seus postulats. D’altra banda, Emilia Pardo Bazán va ressenyar força favorablement el seu llibre, i compartia amb l'autor nicaragüenc el fet d'haver viatjat i haver-ne deixat també una lúcida constància literària. Potser la conclusió més nítida apunti cap a aquesta direcció, que el fet de compartir la condició d'haver escrit cròniques o llibres de viatge, sigui el que uneixi Darío, Rusiñol tant o més que l'estètica modernista - i fins i tot amb Pardo Bazán, per sobre de les diferències estètiques. París torna a ser mirall i prisma alhora. Perquè les Cartas finlandesas de Ángel Ganivet, o les Cartas de Rusia de Juan Valera no semblen esmenar tal apreciació. El títol que Pardo Bazán havia publicat fins aleshores Al pie de la Torre Eiffel, ja marcava una direcció, que en els dies en què Darío escriu sobre ella es reitera amb els articles que anava publicant en una segona estada, i que també acabaven de recollir-se en llibre: Cuarenta días en la Exposición, de l'any 1900.

No hi ha prou, amb viatjar, per esdevenir cosmopolita; el sentit d'aquest cosmopolitisme, el sentit profund d'una estructura intel-lectual oberta des d'allò local a allò universal que no oblidi que totes dues dimensions es troben alhora en els mateixos indrets i detalls, necessitava aleshores el filtre, mirall i marc de París - fins i tot per a poc més tard, poder desprendre-se'n. Però, potser això ja és reconèixer-se necessàriament desplaçat en el viatge. I el viatge a Europa, si inclou Espanya, és especialment problemàtic per la figura de l'escriptor viatger hispanoamericà, ja que, com ha sintetitzat Jacinto Fombona, és:

el destino europeo que provoca una reacción hermenéutica por excelencia. Hay que interpretar e interpelar los espacios españoles. España como "patria" es un lugar cuyos signos el viajero interpreta como dirigidos a su persona, con un significado que le habla de un origen en el cual puede trazar y descifrar una genealogía cultural a la que pertenece. Sin embargo, como espacio hermenéutico, España es también un lugar que abre dudas sobre la validez de cada lectura. Lectura que para cada viajero hispanoamericano implica un constante repaso de las relaciones culturales (y políticas) no sólo entre España e Hispanoamérica, sino entre España y el resto de Europa e incluso entre Hispanoamérica y los Estados Unidos por lo que éstos representan en el mundo cultural europeo. (Fombona, La Europa necesaria 162)

Ara bé: el que no sol remarcar-se clarament és el pes específic de la dimensió política en aquestes cròniques de viatge, i, dins d'aquesta apreciació, el paper 
del catalanisme político-cultural, ${ }^{1}$ que la crítica no sol atendre més que com un rerefons del modernisme o de les estampes urbanes dibuixades per Darío en les primeres pàgines del seu llibre, i no com un element axial en la seva argumentació, que a més a més intensifica la relació de contrast i comparació entre Buenos Aires, Madrid i Barcelona amb París com a capitals dels respectius projectes - $\mathrm{i}$ realitats— nacionals.

\section{EL MERIDIÀ DE MONTMARTRE}

A Barcelona Rubén Darío no exerceix ben bé de Chroniqueur poètic - la qual cosa sí farà amb les cròniques parisenques-, sinó més aviat polític, i reconeix a Barcelona, a la Rambla, el moviment urbà, la ciutat com a moviment eminentment social. La ciutat se li fa recognoscible a Barcelona, al seu boulevard per excel-lència, com un absolut. I la mirada eminentment poètica que impregna el circumstancial periodista resulta indeleble:

Es esta ancha calle, como sabréis, de un pintoresco curioso y digno de nota, baraja social, revelador termómetro de una especial existencia ciudadana. En la larga vía, van y vienen rozándose, el sombrero de copa y la gorra obrera, el smoking y la blusa, la señorita y la menegilda. Entre el cauce de árboles donde chilla y charla un millón de gorriones, va el río humano, en un incontenido movimiento. Si vuestro espíritu se aguza, he ahí que se transparenta el alma urbana. (Darío, España contemporánea, "En Barcelona" 10)

El poeta modernista arriba, però, a una ciutat on percep un altre modernisme que exigeix ser narrat, un modernisme semblant i diferent, que gravita al voltant d'un altre gran cronista de viatges, Santiago Rusiñol. Amb les seves mirades, a través del periodisme literari, Barcelona i Buenos Aires també es desplacen, senten el seu propi moviment. I aquest desplaçament d'una ciutat, que sempre implica una altra, té geografies ineludibles; pel que fa al segle XIX, París és, d'alguna manera, part de la geografia invisible de totes aquestes ciutats, a través de les cròniques que les fan pensables.

La personalització dels noms de les ciutats no és cap exageració. No només es tracta d'un moment en què la capital francesa és la capital del segle XIX, tot i que ja comença a albirar-se clarament el decandiment de l'hegemonia de França en el continent polític; en el continent artístic i literari la seva centralitat en la trama europea encara resulta clara, però per raons que ja no tenen a veure simplement amb els seus propis creadors, sinó amb l'atracció de la ciutat mateixa de creadors de múltiples procedències, fascinats no només per la gran metròpoli, sinó sobretot per la trama artística i literària teixida sobre els seus carrers, en tant que xifra 
de l'agitació i de la novetat. Tal com llegim en les primeres pàgines del llibre de Rusiñol, en relació a Montmartre i el seu Moulin de la Galette:

El molino no solo es el centinela del barrio, sino el centinela del mundo.

Por él pasa el meridiano. Por su cúspide atraviesa ese meridiano de París, que consultan a todas horas del día los geógrafos de la tierra, y a todas horas de la noche los astrónomos que estudian otros mundos. (Rusiñol, Desde el Molino 10-11)

Tractant-se de la primera d'aquestes cròniques que va publicar-se al periòdic, és lògic que mostri una forta impressió d'arribada, de sensacions de nouvingut que, tanmateix, ja sabia on arribava. Un cop installat a la casa mateixa del Moulin "parte de la colaboración de La Vanguardia, representada humildemente", (Rusiñol, Desde el Molino 6) la descripció dels voltants del turó, amb les seves finestres obertes alhora cap al carrer i cap a l'interior dels tallers dels artistes, finestres al darrere de les quals la glòria s'aconsegueix o s'escapa cada dia en la feina de "miles de obreros del arte", la sensació d'entusiasme i cansament alhora fa que les conclusions formulin de manera clara:

Quizás debido a esto no pudimos pegar los ojos, o quizás tuvo la culpa... ¡váyase a saber!... la influencia del meridiano que pasa y pesa sobre nosotros. (Rusiñol, Desde el Molino 13) ${ }^{2}$

Però, si ens centrem en les figures literàries — sense oblidar les pictòriques - cal considerar un petit però important desplaçament en aquest meridià: el paper de mitjancer del món editorial francès entre les diverses literatures europees, que es mantenen al corrent del que fan les unes i les altres a través del filtre de la llengua francesa i del camp editorial francès. Aquest mateix camp editorial, que forneix per igual de lectures franceses i no franceses les elits culturals de diversos països, acabarà desenvolupant un paper clau en les respectives modernitats, en trobar-hi cabuda - per raons tant de mercat editorial com de cosmopolitisme- escriptors en diverses llengües. I aquest factor, al costat dels més evidents:

París está a un paso y me ha sucedido leer en La Nación el juicio de un libro francés antes de que ese libro hubiese llegado a Madrid. El que no encarga especialmente sus libros a Francia, Inglaterra, etc., no puede estar al tanto de la vida mental europea. (Darío, España contemporánea, "Libreros y editores", 207)

Una comanda de llibres estrangers esdevé un acte de creació i consolidació d'un nou camp literari. El que permet aquesta relació són les figures individuals que impulsen els projectes col-lectius més enllà de la recepció o rellevància estricta de les seves obres. Es tracta, doncs, d'una experiència de la modernitat literària constitutiva de la mirada en dos moderns indiscutibles, Darío i Rusiñol, que no poden no tenir París com a referent de la seva imatge i autoimatge, i que, quan 
aquestes mirades es creuen, desplaçades, sense París, continuaran tenint la ciutat del Sena com a rerefons discursiu, la qual cosa no deixava de produir diversos efectes. En aquest cas es tracta sobretot d'un somni modern d'unes capitals - Buenos Aires, Barcelona- que per camins ben diferents troben en París no només el mirall sinó també, el que resulta més decisiu, el context a través del qual concretar els respectius projectes modernitzadors, culturals, ciutadans, polítics i nacionals alhora. I en tots dos processos, l'argentí —o americà- i el català, París resulta ineludible, però no solament per la seva condició de model urbanístic, sinó, en el cas americà, pel que Rama anomena la "terca tradición de la metrópolis conservada en el espíritu de las ex-colonias". En el cas de Buenos Aires respecte a París es tractaria, segons Rama, d'una "Ciudad central que es posible soñar desde la periferia merced a la excitación provocada por las letras y las imágenes, pero que además lleva adelante la propia vida nacional a partir del omphalos de su capital dominadora". En aquest punt, els projectes metropolitans i nacionals es creuen, i donen com a resultat una paradoxa:

la ciudad ideal no copiaba sobre la orilla oeste del Atlántico un preciso modelo europeo, como tantas veces se ha dicho en especial de las siempre más imitativas clases superiores, sino que era también una invención con apreciable margen de original, una hija del deseo que es más libre que todos los modelos reales y aún más desbocada, la que además, al intentar realizarse, entraría en una borrosa amalgama con la terca realidad circundante. (Rama, La ciudad letrada 179-80)

Sense menystenir l'agudesa de l'anàlisi de Rama, en el cas de les cròniques de viatge de Darío la relació esdevé múltiple; els desitjos dels uns i dels altres es diversifiquen en intencions i en resultats: Buenos Aires i Barcelona miraven París a través de les seves elits, però el contrast amb Madrid és tan evident que complica encara més l'apreciació de Rama. Aquest doble triangle farà d'aquelles pàgines de Darío una magnífica exposició crítica del respectius projectes moderns, i del filtre parisenc que permet concebre'ls, en la seva especificitat - americana i europea, portenya i barcelonina - al marge de Madrid i tot el que significava en la cultura espanyola, desposseïda de tot caràcter metropolità. El fet que la realitat circumdant en el viatge inclogui una tercera ciutat, Barcelona, és el que permet a Darío establir distincions tan clares. "En Barcelona" significa el creuament entre l'estètica modernista - generalitzable - i la realitat política, que no es relaciona a través del filtre metropolità amb París, i menys encara amb Madrid. I és el que permet també no confondre el somni modern de les capitals amb la funció de París en la trama de lectures possibles o impossibles; és a dir, en la realitat ja decididament moderna de Barcelona, que és precedida pels seus escriptors.

En aquest sentit és molt rellevant el fet que la primera lectura catalana de Rubén Darío, La Papallona de Narcís Oller, va ser en traducció francesa d'Albert Savine 
publicada en 1886: Le Papillon, llibre que va ressenyar en un diari de Santiago de Xile, La Época, tot al-ludint: "Al movimiento renovador de la literatura catalana conocido por la Renaixença al señalar el progreso de las letras catalanes que están llamadas a iniciar un gran renacimiento. Cabezas privilegiadas inician el gran movimiento, Cataluña tiene a Víctor Balaguer, al presbítero Verdaguer y a otros tantos de alto vuelo". (Rubén Darío: [Ressenya de Le Papillon, d’Àngel Guimerà] citat en Quintián, Cultura y literatura españolas en Rubén Dario 261) Per la seva banda, abans de la trobada parisenca, segurament Santiago Rusiñol va llegir el retrat que Darío va fer de Ricardo Palma sota el títol "Fotograbado", datat en 1890, que el retratat va incloure al seu Tradiciones peruanes, editat a Barcelona. En aquella nota, Darío donava la següent definició:

el Modernismo (...): la elevación y la demostración en la crítica, con la prohibición de que el maestro de escuela anodino y el pedagogo chascarrillero penetren en el templo del arte: la libertad y el vuelo, y el triunfo de lo bello sobre lo preceptivo en la prosa, y la novedad en la poesía: dar color y vida y aire y flexibilidad al antiguo verso que sufría anquilosis, apretado entre tomados moldes de hierro. (Rubén Darío: "Ricardo Palma", 19-20)

Aquesta primera teorització del Modernisme per part de Darío coincideix en data, 1893, amb la Segona Festa Modernista organitzada per Santiago Rusiñol a Sitges. Ja aleshores es pot donar per segura una afinitat estètica innegable, i una evolució paral-lela dels respectius moviments moderns que té una intersecció desplaçada en certs carrers de París, que Darío i Rusiñol van passejar per separat, encara que per arribar al mateix lloc.

La primera estada de Rubén Darío a París va ser en 1893. Darío entra en contacte, gràcies a Enrique Gómez Carrillo, que aleshores treballava per a l'editorial Garnier, i Alejandro Sawa, amb Paul Verlaine, Jean Moréas. És aleshores que coneix també a Santiago Rusiñol, però els seus cercles són tangencials. El nicaragüenc s'instal·la en el Faubourg Montmartre, però sota la influència de la bohèmia simbolista freqüenta sobretot el Quartier Latin, on encara tindrà l'oportunitat de veure — més que conèixer — el seu admirat faune: Verlaine. En canvi, Rusiñol, installat al turó de Montmartre mateix, hi roman de manera preferent, si més no en aquesta primera estada — en una altra, posterior, serà a l'île Saint-Louis on residirà, la qual cosa modificarà força els itineraris narrats. El veritable encontre entre tots dos havia de quedar ajornat.

\section{"EL HERVOR DE LA RAMBLA"}

Les primeres pàgines d'España contemporánea, després del preceptius capítols embarcat que fins fa no gaire precedien tot relat de viatge, no podien sinó causar 
certa estupefacció en una part important dels lectors peninsulars. Però aquesta sensació - força freqüent en la crítica espanyola - parteix d'un error d'apreciació conseqüència lògica de la perspectiva. L'interlocutor literari d'un relat de viatge no sol ser el lector del país visitat — que ben sovint s'assabenta de l'existència d'unes pàgines sobre ell mateix amb bastant retard- sinó el lector del país d'origen del narrador. Aquest fet explica que, en una de les poques ressenyes positives que va rebre el llibre de Rubén Darío en el context espanyol, Emilia Pardo Bazán cometés l'error de parlar de l'autor com d'un "poeta argentino". Aquest malentès es deu sobretot al fet que les cròniques s'escrivissin per a La Nación de Buenos Aires —diari, d'altra banda, com La Publicidad de Barcelona, on sovintejaven les més reputades firmes espanyoles de l'època-, i a què, en els primers capítols, com "En el mar", s'afirmi que "no hay duda de que venimos de Buenos Aires", i en un altre es parli de la "Legación argentina" (Darío, España contemporánea 28). Però també és degut a la perspectiva peninsular mateixa, que en aquests moment considera Amèrica del Sud com un conjunt de trets indistingibles, la qual cosa podia ser només relativament certa pel que fa a una part de les seves elits - i Darío en formava part-, però no en d'altres aspectes igualment rellevants.

Les cròniques de Darío fan un doble viatge, i en aquest punt cal centrar-se en el segon, el de tornada: de tornada d'unes planes on Darío ja havia assolit un gran prestigi com a prosista, que creixerà amb aquestes cròniques i es farà definitiu amb les que enviarà, tot seguit, des de la seva corresponsalia a París. El desplaçament, aquest cop a Europa, transformades en llibre, donarà a aquelles pàgines una nova circulació i uns altres efectes de lectura. El lector espanyol, doncs, queda relegat a una posició diferida, de la qual Darío és perfectament conscient. I, per més que estigués acostumat als judicis literaris dels estrangers — des del Romanticisme, el viatge a les Hespèrides havia concretat una imatge exòtica, gairebé orientalista d'allò espanyol alhora que hi suscitava la necessitat de llegir com eren vistos els espanyols més enllà dels Pirineus-, en aquesta ocasió el desconcert resulta notable, perquè molts d'aquests lectors neguen la diferència de l'escriptor en raó de la identitat lingüística del que aleshores solia anomenar-se l'América española. Aquest fet es dóna en un moment en què es demana a Darío, per part de certs lectors espanyols també escriptors, alguna cosa més que escriure en castellà per sustentar aquesta identitat comuna, en realitat ja inviable des de feia molt de temps, però encara al·ludida de forma recurrent.

En un segon terme, aquelles primeres pàgines no podien ser gaire del grat dels lectors finiseculars espanyols perquè, exclosos de la prioritat narrativa, tampoc no eren els lectors únics, ni homogenis, que s'esperaven d'un títol com aquell, a la península. Des de la perspectiva de l'americà, els trets de la diversitat peninsular són recollits fins i tot abans de començar el viatge, i integrats en la interpretació múltiple, diversa, de l'indret visitat. Entre els lectors peninsulars, les distincions 
que s'estableixen, sobretot en alguns capítols i temes, impliquen que aquelles pàgines tocaven port en la nova fibra sensible de l'anomenat noventayocho: l'entitat política mateixa.

El capítol "En Barcelona" no era la millor manera de començar a narrar aquella estada, si del que es tractava era de mostrar España. Les paraules finals d'aquest capítol perceben una frontera latent, de l'altra banda de la qual escriu:

Ocasión habrá de hablaros de la obra de Rusiñol y los artistas que le siguen, cuando torne a Barcelona a sentir mejor y más largamente las palpitaciones de ese pueblo robusto. $\mathrm{He}$ llegado a Madrid y próximamente tendréis mis impresiones de la corte. (Darío, España contemporánea, "En Barcelona" 20)

Rubén Darío recull, d'una banda, una oposició entre Catalunya i Espanya en què només la primera seria veritablement contemporània - en el sentit modern de la paraula-, especialment en el pla artístic, i la segona no ho seria més que en el calendari, seria simplement coetània, ja que ancorada en la seva tradició, no sembla adonar-se que: "la Tizona de Rodrigo de Vivar no corta ya más que el vacío y que dentro de las viejas armaduras no cabe hoy más que el aire". (Darío, España contemporánea, "Madrid" 26) La contemporaneïtat d'Espanya resulta així una coincidència temporal no vinculada a l'esperit del present.

Però no es tractava senzillament d'això. Buenos Aires i Barcelona protagonitzaven, des de la dècada dels 80 del segle XIX, uns processos de modernització perfectament equiparables, malgrat els seus punts de partida i resultats diferents. El projecte modern, europeïtzador, argentí iniciat per la generació del 80 és parallel a l'europeisme català des de la Renaixença, encara més accentuat des dels primers moments del Modernisme, amb l'exposició de 1888 com a catalitzador, que al seu torn tindria el seu equivalent en l'Argentina del Centenario, en 1910. La dimensió urbana serà un element decisiu, no només per la seva composició - d'orígens internacionals, en el cas de Buenos Aires-, la seva agitació i la seva implicació en el progrés ciutadà, sinó també pel canvi de gravitació que significa en el cas bonaerese convertir-se, en només mig segle, en la ciutat més important del món hispanoparlant: de 242.215 habitants en l'any 1869 , passa a comptar amb 823.178 l'any 1895; poc després, el 1914, el cens arriba als 2.075.077, i només a la Capital Federal, ja hi vivien un milió i mig de persones. ${ }^{3}$ És evident que els lectors de Buenos Aires esperaven les noticies que enviés Darío de Madrid, més que Espanya, per confirmar un relleu que, a partir dels anys vint, esdevindrà inajornable, i que coincidia amb els nous debats sobre la capital de la llatinitat, debats en els quals París reapareix com a element determinant, Buenos Aires com a promesa i Madrid com a irrellevant. "Allí entre nosotros solemos quejarnos. Yo ya no me quejo. Aguardemos nuestro otoño. ¡Oh! argentinos, creed 
y esperad en ese gran Buenos Aires". (Darío, España contemporánea, "Libreros y editores” 216), afirma, en comparar la manca de bones llibreries de Madrid amb les noves, $\mathrm{i}$ ben assortides de llibres estrangers, que van obrint-se a la capital portenya.

Les notícies que Darío tramet de Barcelona estant, a banda de reforçar aquella expectativa, mostren una disputa interna paral-lela que, sens dubte, els incitava a posicionar-se en funció de la semblança. En aquest punt, la complexitat urbana de totes dues ciutats resulta decisiva. El paper de la multitud i de l'obrerisme, amb la força que l'anarquisme va tenir a Barcelona —i també a Argentina, a Buenos Aire, com a conseqüència de la immigració obrera europea-, omple els carrers de l'una i de l'altra de veritables masses proletàries.

Limitar les apreciacions sobre Barcelona i el seu espai públic a la semblança - i semblances - de les estètiques i figures del modernisme significaria aturar-se en una evidència, i no fer-se càrrec del que Darío arriba a percebre. Potser per això, i no només per coherència narrativa del relat de l'arribada a la ciutat, l'article de Darío se situa immediatament a la Rambla; i a la Rambla s'atura un moment en el Café Colon "pues en España, aun estando en Cataluña, la vida de café es notoria y llamativa". (Darío, España contemporánea, "En Barcelona" 11) El que crida la seva atenció notòriament és la composició plural de l'espai públic del Cafè, i del carrer, barceloní:

estaba en el café Colón y cerca de mí en una de las mesitas dos caballeros, probablemente hombres de negocios ó industriales, elegantemente vestidos, conversaban con gran interés y atención, cuando llegó un trabajador con su traje típico y ese aire de grandeza que marca en los obreros de aquí un sello inconfundible; miró a un lado y otro, y como no hubiese mesas desocupadas cerca de allí, tomó una silla, se sentó a la misma mesa en que conversaban los caballeros y pidió como lo hubiera hecho el mismo Vilfredo el Velloso, su taza. Le fue servida; tomóla, pagó y fuese como había entrado, sin que los dos señores suspendiesen su conversación, ni se asombrasen de lo que en cualquiera otra parte sería acción osada e impertinente. (Darío, España contemporánea, "En Barcelona" 11)

És evident que Darío compta amb prou coneixement de la vida de Cafè com per saber que es tracta d'una institució burgesa, però de caràcter obert, on el mer fet de poder-se pagar una tassa de cafè fa inqüestionable la presència en el local de qualsevol individu — sempre dins d'un ordre. (Martí Monterde, Poética del Café) Aquest ordre no és ben bé trencat per la presència de l'obrer en el Cafè, sinó pel fet de compartir taula amb dos homes de negocis, però com que no hi reparen en la seva presencia, la seva manca de reacció implica un efecte de reconeixement. Darío no parla d'impassibilitat, sinó d'imperceptibilitat, ja que la condició d'obrer no ha estat esborrada però sí coberta per l'orgull ciutadà, legitimant-se a si mateix amb la força del treball que es converteix en la capacitat adquisitiva de poder-se pagar, sufragar un cafè, com un industrial, com un empresari, com un comerciant. Així 
doncs, sufragar-se un cafè implica no només una defensa del sufragi universal, constitutiu de la vida democràtica en la ciutat, sinó el sorgiment d'un nou estat de coses, escenificat en el local, però que es projecta en el conjunt de la vida urbana.

Certament, cal considerar una exageració l'al-lusió a Guifré el Pilós per a caracteritzar aquest personatge, però alhora mostra com Darío ja coneix certes mitologies nacionals catalanes abans d'arribar a Barcelona, fins el punt de poder emprar-les tòpicament. I no deixa de ser interessant des del punt de vista del relleu de l'aristocràcia per la classe burgesa, primer, i a la vista d'aquesta escena, en aquest moment també pel proletariat. $\mathrm{O}$, si més no, així ho llegeix Darío, potser alhora que ho desitja. Quan aquest personatge s'acaba el seu cafè i torna al carrer, el narrador el segueix:

Por la Rambla va ese mismo obrero, y su paso y su gesto implican una posesión inaudita del más estupendo de los orgullos; el orgullo de una democracia llevada hasta el olvido de toda superioridad, a punto de que se diría que todos estos hombres de las fábricas tienen una corona de conde en el cerebro. (Rubén Darío, España contemporánea, "En Barcelona" 12)

També cal assenyalar que una comunió ciutadana interclassista com la recollida per Darío s'assemblava poc a la conflictivitat social que convertiria Barcelona en la Rosa de Foc, i que ja aleshores resultava més que perceptible en la ciutat. Però en tot cas, la impressió de Darío no és del tot desenfocada: parla d'una societat de múltiples dimensions, però unificada per trets ciutadans força coherents, en la seva tensió. De fet, és el que ja havia trobat en "el hervor de la Rambla" mateixa, abans d'entrar al local:

Allí, al pasar, notáis un algo nuevo, extraño, que se impone. Es un fermento que se denuncia inmediato y dominante. Fuera de la energía del alma catalana, fuera de ese tradicional orgullo duro de este país de conquistadores y menestrales, fuera de lo permanente, de lo histórico, triunfa un viento moderno que trae algo del porvenir; es la Social que está en el ambiente; es la imposición del fenómeno futuro que se deja ver; es el secreto a voces de la blusa y de la gorra, que todos saben, que todos sienten, que todos comprenden, y que en ninguna parte como aquí resalta de manera tan palpable en magnífico alto-relieve. Que la ciudad condal, que estos hombres fuertes de antiguo, que tuvieron poetas en el Rouy duques de Atenas, que anduvieron en cosas de conquistas y guerras por las sendas del globo, y extendieron siempre su soberbia como una bandera; que esta tierra de trabajadores, de honradez artesana y de vanidad heroica, esté siempre de pie manifestando su musculatura y su empuje, no es extraño; y que el desnivel causante de la sorda amenaza que hoy va por el corazón de la tierra formando el terremoto de mañana, haya aquí provocado más que en parte alguna la actitud de las clases laboriosas que comprenden la aproximación de un universal cambio, no es sino hecho que se impone por su ley lógica. (Rubén Darío, España contemporánea, "En Barcelona" 11) 
Ara bé: a partir d'aquesta percepció social, Darío articula tota una altra sèrie de consideracions que tenen a veure amb l'articulació política d'Espanya, en què Barcelona, Catalunya, ja no encaixen.

\section{MODERNISMES I CATALANISME}

Darío percep clarament com la composició i articulació social, i la força social mateixa, va esclatant tant en el treball com en el conflicte, en el progrés i en la reacció. Aquesta oposició articula una crítica explícita a l'immobilisme d'Espanya, i un recolzament implícit al dinamisme de Catalunya que, en aquells moments, comença a debatre seriosament les alternatives a la seva posició política, i a argumentar-les no només al seu si, o enfront dels possibles interlocutors a Espanya, sinó també davant dels visitants.

Un visitant, en aquest cas Darío, que ja abans d'emprendre el viatge tenia una certa idea d'aquest debat, però que ara es troba amb el fet que diverses persones, des de diverses posicions, l'hi mostren com una qüestió vivament plantejada en les tertúlies i els carrers.

Observo que en todos aquí da la nota imperante, además de esa señaladísima demostración de independencia social, la de un regionalismo que no discute, una elevación y engrandecimiento del espíritu catalán sobre la nación entera, un deseo de que se consideren esas fuerzas y esas luces, aisladas del acervo común, solas en el grupo del reino, única y exclusivamente en Cataluña, de Cataluña y para Cataluña. No se queda tan solamente el ímpetu en la propaganda regional, se va más allá de un deseo contemporizador de autonomía, se llega hasta el más claro y convencido separatismo. Allí sospechamos algo de esto; pero aquí ello se toca, y nos hiere los ojos con su evidencia. (Rubén Darío, España contemporánea, "En Barcelona" 12)

Al costat de la Revolució Social, el trencament amb Espanya forma part de la mirada a una Barcelona que encapçala, com Buenos Aires, un projecte d'abast nacional. I, de Buenos Aires estant, ja era perceptible el que la presència fa palès. No deu passar inadvertit que l'enunciat "hiere los ojos" no implica necessàriament una apreciació de desgrat, sinó d'enlluernament ineludible. I aquesta no deixa de ser una de les convencions del llibre de viatges a indrets una mica coneguts en la distància: la confirmació, amb escreix, de les informacions de què hom disposa abans de l'arribada. En aquest cas, la circulació dels debats polítics prepara una apreciació que, un cop enmig d'aquell debat, resulta desbordada en la seva constatació.

En realitat, això tenia poc a veure amb la independència de Cuba, rerefons del reportatge, - on d'altra banda, el paper dels catalans no va ser precisament gaire 
lluït, ni menys encara diferent substantivament de la d'altres neocolonitzadors del segle XIX. La pèrdua de Cuba és només un context, no un rerefons. Tot una altra qüestió és que sigui, precisament, la riquesa generada a les colònies pels indianos el que permeti als joves modernistes construir la seva autonomia artística al marge de les preocupacions econòmiques, de la mateixa manera que els seus pares bastien edificis d'estiueig on s'entapissaven les estances amb Indianes i les façanes amb motius al-legòrics d'aquella situació. Res de tot això converteix la relació entre Barcelona i Madrid en una dialèctica colonial. Per molt que de vegades es vulgui fer un reduccionisme a situacions postcolonials, i per molt que s'hi pugui adduir la retòrica del Decret de Nova Planta, aquesta simplificació ha de ser considerada fal-laç: la Barcelona industriosa del segle XIX no es comporta, en cap moment, com una colònia, mentre que per la capital argentina, aquesta situació és un passat formalment superat, institucionalment acabat, però que encara no té tots els aspectes problemàtics resolts, ni molt menys, pel que fa a la percepció que se'n té des d'Espanya. Mirar de llegir en clau colonial-postcolonial el debat CatalunyaEspanya és no només una ingenuïtat, també un rebaixament de la seva complexitat i la dissolució de la posició de força de Barcelona en una actitud que no té res a veure amb la realitat: resulta impensable que una colònia es plantegi regenerar políticament, culturalment, socialment o econòmicament la potència dominadora, sobretot si tenim present que tal potència ja no n'és, i que a sobre forma part de la mateixa geografia peninsular, amb Portugal.

Això ho aprecia molt bé Darío, que en cap moment explica la dimensió i força socials del catalanisme en relació als esdeveniments recents d'ultramar. Però no és menys cert que el comentari de la realitat catalana en aquest llibre s'hi troba implicat en la mirada americana a la crisi de fi de segle a Espanya. Perquè, en la seva perspectiva, Madrid és ultramar, com Barcelona. I totes dues són mirades amb un filtre francès.

Per això la seva percepció de Catalunya és específica. I de la seva especificitat, Darío no dubta a desprendre les següents conclusions alhora que realitza una afuada caracterització de les diverses posicions:

Hace poco, en una fiesta industrial, en momentos en que llegaban amargas noticias de la guerra, ciertos trabajadores arrancaron de su asta una bandera de España y la sustituyeron por una bandera roja. Mientras esto pasa en la capa inferior, arriba y en la zona media, cada cual por su lado, se mueven los autonomistas, los francesistas y los separatistas. Los unos quieren que Cataluña recobre sus antiguos derechos y fueros, que no le fueron quitados sino al comenzar este siglo; los otros pretenden la anexión a Francia, yo no sé por qué, pues la centralización absoluta de allá les pondría a lo mejor, en el mismo caso que el Poitou ó la Provenza, y las reales relaciones y simpatías con el vecino francés no pasan de vagas y platónicas manifestaciones de felibres; una cigarra canta de este lado, otra contesta del otro: no creo que entre Mistral y Mossén Jacinto Verdaguer vayan a lograr mejor cosa. 
Los otros sueñan con una separación completa, con la constitución del Estado de Cataluña libre y solo. Claro es que, además de estas divisiones, existen los catalanes nacionales, o partidarios del régimen actual, de Cataluña en España; pero éstos son, naturalmente, los pocos, los favorecidos por el gobierno, o los que con la organización de hoy logran ventajas o ganancias que de otra manera no existirían.

Entretanto, trabajan. Ellos han erizado su tierra de chimeneas, han puesto por todas partes los corazones de las fábricas. Tienen buena mente y lengua, poetas y artistas de primer orden; pero están ricamente provistos de ingenieros é industriales. (Darío, España contemporánea, "En Barcelona” 15)

La qüestió del pas del regionalisme a l'anomenat separatisme és plantejada de manera continua, no merament contigua, a la qüestió social, i a partir d'aquesta transversalitat de la desafecció per Espanya analitza les diverses alternatives aleshores en debat, amb una gran lucidesa comparativa, si atenem a la consciència de la realitat cultural del felibritge occitanista i del català al Rosselló. Fins i tot la perspectiva dels partidaris de romandre dins d'Espanya és plantejada en uns termes, ben actuals, que exposats de manera tan clara fins i tot avui dia incitarien a una notable polèmica.

Però, fonamentalment, les argumentacions del nicaragüenc s'articulen sobre la pròpia modernitat barcelonina, i, tal como passa en els grans projectes modernitzadors, es vincula la força de la capital amb la vertebració del país: la idea de gran ciutat com a motor nacional, com en el cas argentí, o abans en el cas francès del segon Imperi, fa de Barcelona el lloc on es mostren alhora les contradiccions de la situació i les seves possibilitats, a través de la hipotètica ruptura, que no pren les forces merament del discurs romàntic, sinó del liberalisme de caràcter urbà. Per això els seus interlocutors sobre la qüestió nacional, a Barcelona, són tan diversos, perquè en el debat nacional participa tot el cos social català, representat amb totes les seves forces i respectives opcions:

Dan gran copia de razones y argumentos, desde que uno toca el tema, y no andan del todo alejados de la razón y de la justicia. He comparado durante el corto tiempo que me ha tocado permanecer en Barcelona, juicios distintos y diversas maneras de pensar que van todas a un mismo fin en sus diferentes modos de exposición. He recibido la visita de un catedrático de la Universidad, persona eminente y de sabiduría y consejo; he hablado con ricos industriales, con artistas y con obreros. Pues os digo que en todos está el mismo convencimiento, que tratan de sí mismos como en casa y hogar aparte, que en el cuerpo de España constituyen una individualidad que pugna por desasirse del organismo a que pertenecen, por creerse sangre y elemento distinto en ese organismo, y quién con palabras doctas, quién con el idioma convincente de los números, quién violento y con una argumentación de dinamita, se encuentran en el punto en que se va a la proclamación de la unidad, independencia y soberanía de Cataluña, no ya en España sino fuera de España. (Darío, España contemporánea, "En Barcelona” 12-13) 
En aquest punt, val a dir que Barcelona és considerada el centre d'un nacionalisme constructiu, factor de modernització en el qual, com ha assenyalat amb lucidesa Vicente Cacho, com en la resta d'Europa, liberalisme, socialisme i nacionalisme constitueixen una constel·lació teòrica que, en el cas català, esdevé clau perquè la modernització sigui efectiva i profunda.

Ara bé: com Darío constata en temps real, Catalunya comença a contestar nítidament els entrebancs que Espanya significa en aquesta modernització, i l'ús dels termes col-lectius i el subratllat de la seva diversitat ideològica i de classes resulta pertinent, a l'entendre de Cacho, qui assenyala "el acierto de los jóvenes nacionalistas catalanes de fin de siglo al situar decididamente en el plano de la sociedad, y no en el de la política, la afirmación nacionalista", en línia amb el que els principals teoritzadors europeus del moment havien fet en els seus respectius contexts; és a dir: "Fue el recurrir a un pueblo, con todas sus potencialidades de progreso, aunque también con todas sus inercias seculares, lo que permitió ir haciendo progresivamente realidad, formulándola en términos renovadores la utopía que inicialmente aceptaban tan solo unos pocos patriotas" (Cacho Viu: El nacionalismo catalán 29-30). Aquesta situació de la societat catalana, intensificada en els carrers de la capital, centre i motor del procés i del progrés, és la que Darío es troba en arribar a Barcelona, formulant-se una sèrie de preguntes que recull i fa seves:

Y riente, alegre, bulliciosa, moderna, quizá un tanto afrancesada y por lo tanto graciosa, llena de elegancia. Barcelona sostiene lo que dice, y dice que habría hecho mucho más de lo que hoy nos asombra y nos encanta, si se lo hubiese permitido la tutela gubernativa, pues no puede abrir una plaza si no va la licencia de la corte, y de la corte van los ingenieros y los arquitectos y los empleados, a agriar más la levadura; y así, a pasos, a pasos cortos, han adelantado, se han puesto los catalanes a la cabeza. ¿Qué habría hecho Cataluña autónoma, esta gran Cataluña a cuya faz maravillosa he creído contemplar bajo el azul, ya a la orilla de su bravo mar, ya en momentos crepusculares y apacibles, sobre los juegos de agua de su paseo favorito, en donde un simulacro divino rige armoniosamente una cuadriga de oro? (Darío, España contemporánea, "En Barcelona" 14)

A aquesta qüestió de la pluralitat del catalanisme i la seva contextualització s'afegeix el fet que Darío no esborra — com fan d'altres viatgers a la península - la diferència lingüística, que ja hem vist que considera clau, al costat de la industrial i obrera. Ja en les primeres pàgines de la primera crònica recull un diàleg, a la Rambla mateixa sota l'estàtua de Colon, i assenyala: "Lástima es que no pueda darlo en catalán como lo oí, pues ganaría en hierro" ("En Barcelona" 9). En parlar de Rusiñol, fins i tot arriba a afirmar que "Bellamente, noblemente, a la cabeza de la juventud, Rusiñol, que no escribe sino en catalán, pone en Cataluña una corriente de Arte puro, de generosos ideales, de virtud y excelencia trascendentes" 
(Darío, España contemporánea, "En Barcelona" 17). I quan visita finalment Els Quatre Gats, insisteix en què:

Naturalmente, los títeres de los Quatre Gats hablan en catalán, y apenas me pude dar cuenta de lo que se trataba en la escena. Era una pieza de argumento local, que debe de haber sido muy graciosa, cuando la gente reía tanto. Yo no pude entender sino que a uno de los personajes le llovían palos, como en Moliere; y que la milicia no estaba muy bien tratada. (Darío, España contemporánea, "En Barcelona” 19)

De fet, a diferència de la transcripció del diàleg inicial sentit al capdavall de la Rambla, en el moment en què Pere Romeu li fa a mans un anunci, Darío no dubta a transcriure'l en català, per a després afegir:

Ese cabaret es una de las muestras del estado intelectual de la capital catalana, y el observador tiene mucho en donde echar la sonda. Desde luego, sé ya que en Madrid me encontraré en otra atmósfera, que si aquí existe un afrancesamiento que detona, ello ha entrado por una ventana abierta a la luz universal, lo cual sin duda alguna, vale más que encerrarse entre cuatro muros y vivir del olor de cosas viejas. Un Rusiñol es floración que significa el triunfo de la vida moderna y la promesa del futuro en un país en donde sociológica y mentalmente, se ejerce y cultiva ese don que da siempre la victoria: la fuerza. Rubén Darío, (Darío, España contemporánea, "En Barcelona” 20)

Però cal recordar que del primer que dóna compte Darío en el seu llibre és del fenomen de la capital catalana, i de la seva complexitat. Són força recurrents els comentaris sobre l'afrancesament de Els Quatre Gats, i per extensió de la vida cultural barcelonina durant l'època modernista. Certament, aquesta seria la connexió més evident amb el Santiago Rusiñol que havia conegut a París, i que de París havia portat aquesta definició de local bohemi, més proper a la taverna que al Cafè, però que desenvolupava la funció intel·lectual d'aquesta darrera institució de la modernitat literària europea. Cap al carrer Montsió, doncs, s'encamina Darío, perquè:

Me dijeron que podía encontrar a Rusiñol en el café de los Quatre Gats. Allá fui. En una estrecha calle se advierte la curiosa arquitectura de la entrada de ese rincón artístico. Pasé una verja de bien trabajado hierro, y me encontré en el famoso recinto con el no menos famoso Per[e] Romeu. Es éste el dueño, o empresario principal del cabaret; alto, delgado, de larga melena, tipo del Barrio Latino parisiense, y cuya negra indumentaria se enflora con una prepotente corbata que trompetea sus agudos colores, no sé hasta qué punto pour épater le bourgeois. [...] Los cuatro gatos son algo así como un remedo del Chat Noir de Paris, con Per Romeu por Salís, un Salís silencioso, un gentilhombre cabaretier que creo que es pintor de cierto fuste, pero que no se señala por su sonoridad. (Darío, España contemporánea, "En Barcelona" 18) 
El cercle està tancat, la realitat de l'afrancesament barceloní esdevé fantasmagoria en la semblança. Però el que queda de la intersecció d'una i altra és una sensació que també es dóna a la capital argentina: la d'estar en dos llocs alhora, en el propi indret $\mathrm{i}$ en el vast món d'una xarxa de ciutats i països relacionats per un mateix tarannà modern. I aquesta és la gran diferència cultural entre aquestes dues ciutats, amb París com a model i extensió del propi camp literari, i la capital d'Espanya excepció feta, i desplaçada, de Gómez Carrillo, editor de Garnier, i de Alejandro Sawa, no menys desplaçats, i en el cas del segon, de manera gairebé tràgica.

\section{EL MODERNISME COM A COSMOPOLITISME}

Una de les disquisicions més significatives sobre la diferència entre Catalunya i Espanya que Darío assenyala és, com hem vist, la relativa al Modernisme en termes estètics; però del seu vincle amb la política es desprèn que les seves meditacions tenen sempre també un component ciutadà. Perquè és la mateixa definició de ciutadania la que es posava en joc, en l'articulació, o no, dels referents moderns. I aquesta articulació desborda els límits locals o nacionals, precisament alhora que els defineix. El modernisme, com altres grans corrents espirituals, és internacional. Però ni aquesta internacionalitat resulta senzilla d'articular, ni és percebuda de manera neutra per part dels diversos lectors del seu reportatge.

Lògicament, es tractava d'alguna cosa més que una percepció distanciada, i qualsevol argumentació de l'autor respecte d'aquesta dimensió internacional no deixa de gravitar sobre la seva pròpia experiència amb la literatura i la crítica espanyola, especialment amb la reacció que la seva poesia havia produït en alguns autors espanyols. Però, més enllà de la recepció de la seva pròpia obra, hi ha una estructura susceptible de ser comentada que parteix de la premsa i s'estén fins a les arts plàstiques: "Caso muy distinto sucede en la capital del principado catalán”, o que "En pintura, el modernismo tampoco tiene representantes, fuera de algunos catalanes", són arguments reiterats en tot el llibre, també en els passatges en què, tot donant compte del que trobava a Madrid, se'n recorda del que havia conegut a Barcelona:

Puede verse constantemente en la prensa de Madrid que se alude al modernismo, que se ataca a los modernistas, que se habla de decadentes, de estetas, de prerrafaelistas con "s" y todo. Es cosa que me ha llamado la atención no encontrar desde luego el menor motivo para invectivas o elogios, o alusiones que a tales asuntos se refieran. No existe en Madrid, ni en el resto de España, con excepción de Cataluña, ninguna agrupación, brotherhood, en que el arte puro - $\mathrm{o}$ impuro, señores preceptistas - se cultive siguiendo el movimiento que en estos últimos tiempos ha sido tratado con tanta dureza por unos, con tanto 
entusiasmo por otros. El formalismo tradicional, por una parte; la concepción de una moral y de una estética especiales, por otra, han arraigado el españolismo, que, según don Juan Valera, no puede arrancarse "ni a veinticinco tirones". Esto impide la influencia de todo soplo cosmopolita, como asimismo la expansión individual, la libertad, digámoslo con la palabra consagrada, el anarquismo en el arte base de lo que constituye la evolución moderna o modernista. (Rubén Darío, España contemporánea, "El Modernismo” 311)

Aquesta anotació, datada el 28 de novembre de 1899, constitueix sens dubte una reformulació de l'ideari modernista en relació a les seves possibilitats ibèriques i les impossibilitats hispàniques, que crida a superar. D'una banda, no pot passar inadvertida la manera com Darío planteja la seva resposta a les crítiques rebudes com una discussió sobre els temps relatius de les respectives tradicions. De l'altra, l'excepcionalitat de Barcelona és respecte a Espanya, respecte al corrent cosmopolita, al "soplo cosmopolita”. Aleshores, tant Buenos Aires com Barcelona, són ciutats on la vida estava irisada per la tipografia, tant la de la premsa diària com per les revistes, com passava a París, la qual cosa Rubén Darío no s’estarà de valorar com un dels signes d'afinitat: retratistes, il-lustradors i caricaturistes, cartellistes, arts decoratives, revistes, són considerats com una estructura desenvolupada a Catalunya, incipient a Madrid, imprescindible de qualsevol manera si es vol atènyer una afinitat amb el ritme imparable de les novetats. ${ }^{4}$ L'excepcionalitat de Catalunya, doncs, la situa en el mateix tempo gràfic que la capital americana, i en línia amb el de la francesa:

Los catalanes sí han hecho lo posible, con exceso quizá, por dar su nota en el progreso artístico moderno. Desde su literatura, que cuenta, entre otros, con Rusiñol, Maragall, Utrillo, hasta su pintura y artes decorativas, que cuentan con el mismo Rusiñol, Casas, de un ingenio digno de todo encomio y atención; Pichot y otros que, como Nonell-Monturiol, se hacen notar no solamente en Barcelona, sino en París y otras ciudades de arte y de ideas. [...] Desde L'Avenç hasta el Pél y Ploma, que hoy sostienen Utrillo y Casas, se ha visto que existen elementos para publicaciones exclusivamente "modernas", de una élite artística y literaria. Pél y Ploma es una hoja semejante al Gil Blas Illustré, de carácter popular, mas sin perder lo aristo; y siempre en su primera plana hay un dibujo de Casas, que aplauden lápices de Munich, Londres o París. El mismo Pere Romeu, de quien os he hablado a propósito de su famoso cabaret de los Quatre Gats, ha estado publicando una hoja semejante, con ayuda de Casas, y de un valor artístico notable. (Darío, España contemporánea, "El Modernismo" 316)

Resulta força curiosa l'enumeració que fa el poeta, ja que situa Utrillo entre els escriptors, i reconeix Rusiñol en tots dos perfils de modernista. El fet que Darío conegui les revistes que esmenta li dóna aquesta perspectiva múltiple de les figures del modernisme català, importantíssima, ja que si bé és cert que quan Casas i Rusiñol s'instal-len en el Moulin de la Galette, ja hi havien esdevingut 
totes les transformacions artístiques que hi cabien — sense treure'ls mèrit ni reconeixement pel que fa a la introducció a Catalunya d'aquestes tècniques i tendències pictòriques - no és menys cert que les cròniques de Rusiñol, com les d'Utrillo i Casas en 1900, impliquen la literatura periodística com a aportació determinant. I, en aquest punt, no es pot parlar de cap décalage.

Però aquesta qüestió, que aparentment podria semblar limitada a la poètica o a l'estètica modernistes, implica també una consideració sobre el lloc de la modernitat pròpia en el context d'una contemporaneïtat que, necessàriament, vincula el regeneracionisme amb el cosmopolitisme. En aquest punt, les distàncies són clares. En el diari barceloní La Publicidad, el 7 d'abril de 1901, apareixia una ressenya de Leopoldo Alas "Clarín" que mostrava molt clarament la recepció que, entre els principals escriptors espanyols del darrer terç del segle XIX, podien tenir els comentaris del poeta periodista. Ara no subratllarem la reacció a la impressió que Darío ofereix d'España, o del mateix "Clarín”, en les seves pàgines, sinó a la perspectiva mateixa:

Al dejar España, nos deja un libro que se titula así: España contemporánea... pero Darío, más francés que español en todo, hasta ha preferido las prensas de París para su libro, que le publica Garnier. Aunque la cosa va en castellano, a veces hasta Bueno, el último capítulo se titula "Certámenes y expositiones", así, con t; errata simbólica, pues significa, y parece que no, el galicismo de corazón que Darío lleva en las entrañas.

Sí; yo siento decírselo a mi amigo Darío, y más lo sentiré si no le gusta la noticia; su defecto, mayor diría inconveniente, serio, grave, incurable tal vez, es esa blandura con que, al educarse, se ha dejado sugestionar por la forma francesa. (Leopoldo Alas "Clarín": [ressenya de] "España contemporánea de Rubén Darío" 1)

Tornem, doncs, a les cobertes dels llibres com a signe ruptura de la tradició de la llengua per substituir-la per la tradició literària. Publicar en el camp editorial francès resulta un acte de desobediència de les obligacions de la tradició hispànica, en què resultava inherent que la consagració d'un escriptor americà en llengua castellana només podia venir de trobar un editor espanyol. Però, en el moment en què Darío escriu España contemporánea, la situació editorial a la metròpoli, paradoxalment, no resulta gaire galdosa: "Hasta hace poco tiempo — y aun hoy mismo, en la mayor parte de las repúblicas, hacia el norte- el sueño rosado de un escritor hispanoamericano era tener un editor en España", però aquesta temptativa ja no té un veritable referent a la capital española: "He querido explorar ese punto en España, y en verdad os digo que he salido del antro vestido de desilusión. Editores y libreros desconsuelan" (Darío, España contemporánea, "Libreros y editores" 201). Per tant, l'afinitat literària ve a solidaritzar-se amb la germandat editorial dels Garnier, en un moment en què a Buenos Aires tot just comença a articular-se el camp editorial — mentre que en el cas català, Darío reconeix que 
els llibres de "l'Avenç, por ejemplo, no tiene nada que envidiar a empresas como el Mercure de France, ó la de Deman, de Bruselas" (Darío, España contemporánea, "Libreros y editores" 201). No deixa de ser, encara, un desig més que una realitat sòlida, tan en un cas com en l'altre; però el que és inequívocament real és que la decisió d'editar a París resulta coherent en tots aquests plans, i que per la seva banda, com ha resseguit Pura Fernández ("La editorial Garnier de París” 603-12) un editor que era incapaç de dir ni buenos días als seus autors, en canvi, ja havia entès en el tombant de segle que el mercat peninsular resultava insignificant, comparat amb les potencialitats de l'americà, tant pel que fa al mercat editorial i la seva incardinació institucional en els processos d'alfabetització i escolarització, com quant a les figures literàries emergents.

Com es pot apreciar en la reacció de Clarín, no es tracta només d'una qüestió de preferències editorials, o de pèrdua d'influència i domini del camp literari i editorial espanyol sobre l'amèrica, sinó d'una preocupació que no resulta exagerat considerar espiritual: per a l'autor de La Regenta, hi ha en l'autor d'España Contemporánea una "sugestión francesa que ha contrahecho el espíritu del joven americano, tal vez de modo irremediable" (Clarín, [ressenya de] "España contemporánea 1) I, en tant que espiritual, malaltissa: "Sí; el mayor defecto de este libro, tan discreto en muchas cosas, es esa nota cursi, del mal francés, que tiene inundado el espíritu de Rubén Darío". (Clarín, [ressenya de] "España contemporánea 1). No resulta sorprenent el to d'aquestes consideracions perquè, de fet, al marge del que signifiqui España contemporànea, Leopoldo Alas ja havia anat fent observacions semblants, si més no des de 1893:

El señor Darío es muy decidor, no cabe negarlo; pero es mucho más cursi que decidor, y para corromper el gusto y el idioma y el verso castellano, ni pintado. No tiene en la cabeza más que una indigestión cerebral de lecturas francesas y el prúrito de imitar en español ciertos desvaríos de los poetas franceses de tercer orden que quieren hacerse inmortales persignándose con los pies y gracias a otras dislocaciones. (Clarín, "Revista mínima” 1)

Pot agradar més o menys el terme cosmopolita, que aleshores es trobava sotmès a un profund debat a França - en el context de la seva pròpia crisi del quatre-vingt dix-huit, data de publicació del "J'accuse" de Zola-, però fora de França, especialment a Amèrica, els valors d'aquell mot romanien encara en vigor. Si bé es cert que Clarín té raó en assenyalar una confusió generalitzada i interessada entre cosmopolita i francès - "lo universal, (que no es lo parisiense)", (Clarín [ressenya de] "España contemporánea de Rubén Darío", 1) confusió sustentada i impulsada des de l'existència mateixa de la idea de civilització francesa, cal recordar que en aquells moments, en plena incandescència de l'afer Dreyfus entès com a debat sobre el qual es refundarà el nacionalisme francès, resulta més discutible que es consideri com a mera impostura "esa triste admiración genèrica por lo que viene de 
París; y ese culto a todo lo que va dicho en francés, que adquiere para Darío, como para muchos, sólo por ser francés, un mérito, una ventaja”. (Clarín [ressenya de] "España contemporánea de Rubén Darío", 1) El que més molesta a Clarín —que no desconeix pas la tradició literària francesa, i que no hauria pas pogut escriure la seva màxima obra, La Regenta, sense haver llegit, i molt profundament, Madame Bovary de Gustave Flaubert-, és, en realitat, "lo de hacer versos espanyoles que parezcan traducidos del francés". (Clarín [ressenya de] "España contemporánea de Rubén Darío", 1) I, certament, no anava mal encaminada la crítica del novelista: el mateix Darío no s'estava de subratllar que "Mi adoración por Francia fue, desde mis primeros pasos espirituales, honda e inmensa. Mi sueño fue escribir en lengua francesa..." (Rubén Darío: "Los colores del estandarte", 63) És una qüestió que, des de les "Palabras liminares" de Prosas profanas (1896): "Mi esposa es de mi tierra, mi querida de París" (Darío, Prosas profanas 763) havia estat objecte de les més diverses interpretacions i discussions.

Interpretacions i discussions que tenien una clara ambivalència: no era només una qüestió a dilucidar exclusivament al voltant de l'autor d'aquell article, "Los colores del estandarte", publicat abans de fer el viatge a l'Espanya del tombant de segle. Un cop meditades les possibilitats de fer cristal-litzar aquesta adoració en llengua castellana, afegia que en realitat era només en Amèrica on tal cosa era imaginable, "puesto que España está amarullada de tradición, cercada y erizada de españolismo". (Darío, "Los colores del estandarte”, 64) De fet, la preocupació per l'absència de l'element tradicional espanyol havia estat una constant en les crítiques dels seus primers llibres, donant-se situacions tan paradoxals com la que havia suscitat la publicació de $A z u l$, que en 1888 porta Juan Valera a escriure, en una de les seves Cartas americanas:

Con el galicismo mental de Ud. no he sido sólo indulgente, sino que hasta le he aplaudido por lo perfecto. Con todo, yo aplaudiría muchísimo más, si con esa ilustración francesa que en usted hay se combinase la inglesa, la alemana, la italiana, y epor qué no la española también? Al cabo, el árbol de nuestra ciencia no ha envejecido tanto que aun no pueda prestar jugo, ni sus ramas son tan cortas ni están tan secas que no puedan retoñar como mugrones del otro lado del Atlántico. De todos modos, con la superior riqueza y con la mayor variedad de elementos, saldría de su cerebro de Ud. algo menos exclusivo y con más altos, puros y serenos ideales: algo más $a z u l$ que el azul de su libro de usted: algo que tirase menos a lo verde y a lo negro. Y por cima de todo, se mostrarían más claras y más marcadas la originalidad de Ud. y su individualidad de escritor. (Valera: "Azul", Cartas americanas 236-37)

Resulta imprescindible subratllar que, des de la perspectiva de Valera, resulta senzill integrar l'element espanyol, al costat dels altres, en el calidoscopi de referències palpables en l'obra del poeta, fins el punt que Luis Monguió ("De 
la Problemática del Modernismo" 77) ha arribat a considerar aquestes paraules com una invitació al cosmopolitisme. Si fos tan fàcil, si es tractés d'una mera juxtaposició, el modernisme no hauria significat cap problema per la cultura espanyola finisecular; l'actitud de condescendència de l'autor de Pepita Jiménez, però, impedeix tal transparència, que no és individual, sinó estructural. La ruptura era condició de possibilitat del modernisme, precisament per la incapacitat de gran part dels escriptors espanyols d'apreciar-hi res més que un menysteniment de la pròpia tradició: una tradició que implicava la supeditació acrítica d'allò americà a allò espanyol. En aquesta tessitura, les poques i incipients excepcions espanyoles dins tal context resulten, senzillament, irrellevants.

En aquesta situació, i davant aquestes reaccions, Darío replicarà que ell no és pas el culpable d'haver "contagiado a la juventud de América", del que Clarín anomenava el "mal francés" i Valera "galicismo mental", sinó que

La innegable decadencia española aumentó nuestro desvío, y el verdadero o aparente aire de protección mental y de desprecio que respecto al pensamiento de América manifestaron algunos escritores peninsulares secó en absoluto nuestras simpatías y los alejó tanto de la antigua madre patria, que la actual generación intelectual, los pensadores y artistas que hoy representan el alma americana, tienen más relación con cualquiera de las naciones de Europa, que con España. Y tuvimos entonces que ser políglotas y cosmopolitas y nos comenzó a venir un rayo de todos los pueblos del mundo. (Rubén Darío, "María Guerrero" citat en Antonio Vilanova, pròleg a España contemporánea 15)

L'afirmació "Buenos Aires. Cosmópolis", amb què el pròleg de Prosas Profanas increpava al "abuelo espanyol de barba blanca", Rubén Darío: "Palabras liminares", Prosas profanas 763) ha pres cos de manera definitiva poc després d'aquell llibre. Aquests arguments, que Darío havia publicat a La Nación el 12 de juny de 1897, es reafirmen en "El Modernismo", el capítol d'Espanya contemporània en què més clarament s'exposa com les mateixes argumentacions generacionals americanes serveixen pràcticament per mostrar la ruptura catalana amb Espanya;

En América hemos tenido ese movimiento antes que en la España castellana, por razones clarísimas: desde luego, por nuestro inmediato comercio material y espiritual con las distintas naciones del mundo, y principalmente porque existe en la nueva generación americana un inmenso deseo de progreso y un vivo entusiasmo, que constituye su potencialidad mayor, con lo cual poco a poco va triunfando de obstáculos tradicionales, murallas de indiferencia y océanos de mediocracia. [...] Y digo: esto no será modernismo, pero es verdad, es realidad de una vida nueva, certificación de la viva fuerza de un continente. (Darío, España contemporánea, "El Modernismo" 314)

Per això resulta tan important subratllar que el pensament modern, en el cas català, 
no desvincula el pla intel-lectual del polític i social, i precisament per això, el catalanisme resulta un factor decisiu de modernització i d'universalització.

Ja "En Barcelona" havia quedat força clar que aquests trets del catalanisme resultaven determinants, i no només per constituir una oposició al projecte polític espanyol, sinó precisament per tot el contrari: per plantejar-se independentment de la relació, ineludible en altres plans, amb el camp intel·lectual i polític espanyol. Per Darío, el més important que veu a Catalunya és:

movimiento intelectual que ha seguido, paralelamente, al movimiento político y social. Esa evolución que se ha manifestado en el mundo en estos últimos años y que constituye lo que se dice propiamente el pensamiento "moderno" ó nuevo, ha tenido aquí su aparición y su triunfo, más que en ningún otro punto de la Península, más que en Madrid mismo; y aunque se tache a los promotores de ese movimiento, de industrialistas, catalanistas, o egoístas, es el caso que ellos, permaneciendo catalanes, son universales. La influencia de ese grupo se nota en Barcelona no solamente en los espíritus escogidos, sino también en las aplicaciones industriales, que van al pueblo, que enseñan objetivamente a la muchedumbre; las calles se ven en una primavera de carteles o affiches que alegran los ojos en su fiesta de líneas y colores; las revistas ilustradas pululan, hechas a maravilla: las impresiones igualan a las mejores de Alemania, Francia, Inglaterra o Estados Unidos, tanto en el libro común y barato como en la tipografía de arte y costo. (Darío, España contemporánea, "En Barcelona” 16")

En aquest punt cal tenir present com es distribueixen les tensions nacionals envers el modernisme - i el seu cosmopolitisme o internacionalisme - dins la literatura espanyola. Mentre Valera i Clarín semblen orientar les seves discussions respecte a les dimensions polítiques del modernisme americà, pel que fa al modernisme català són Miguel de Unamuno i, sobretot, Pío Baroja, els qui s'ocuparan de debatre i rebatre la concomitància entre projectes polítics i moviments culturals - la qual cosa, en el cas d'Unamuno, s'accentuarà sobretot a partir del sorgiment del Noucentisme. Valera és qui de seguida va plantejar la nova estètica com una forma de desarrelament, en entendre que,

Si el libro, impreso en Valparaíso, en este año 1888, no estuviese escrito en muy buen castellano, lo mismo pudiera ser de un autor francés, que de un italiano, que de un turco o un griego. El libro está impregnado de espíritu cosmopolita. Hasta el nombro y apellido del autor, verdaderos o contrahechos y fingidos, hacen que el cosmopolitismo resalte más. Rubén es judaico, y persa es Darío: de suerte que, por los nombres, no parece sino que Ud. Quiere ser o es de todos los países, castas y tribus. (Valera, Cartas americanas, 214-15)

Pel que fa a Baroja i el Modernisme català, cal remarcar que, en 1907, no va dubtar en fer una associació d'idees que només pot sorprendre relativament: "Los caracteres generales de la intelectualidad judía son en todas partes la habilidad, 
la tendencia internacionalista, el odio a la guerra y a todo lo violento y el amor al lujo", (Baroja "El problema catalan. La influencia judía" 1) la qual cosa, per descomptat, no hauria d'entendre's en termes pejoratius si no fos pel to que traspua aquesta caracterització, a la qual afegeix que "el catalán intelectual es emigrante y se desnacionaliza pronto, y en esto asoma el judío. [...] Yo no sé si estos escritores y artistas catalanes [Fortuny, Casas, Rusiñol, entre d'altres] la mayoría poco amigos de España, son semitas o no; pero lo parecen". (Baroja "El problema catalan. La influencia judía" 1) La novetat més sorprenent d'aquestes argumentacions en contra del cosmopolitisme modernista és la síntesi d'antisemitisme, antimodernisme i anticatalanisme en una sola percepció, que es desenvoluparà poc més tard, encara més detalladament, en 1910:

Barcelona me parece una ciudad exuberante, en la cual, a pesar del cosmopolitismo que producen los puertos concurridos como el suyo, se mantiene íntimamente hispánica, extraordinariamente española.

En cambio, la producción intelectual barcelonesa, ¿qué impresión da? Hay drama en catalán que parece escrito en Noruega; versos que parecen confeccionados en el bulevar de Montmartre; comedias lacrimosas, como las de Rusiñol, en las cuales se encuentra uno como disuelto en un mar de merengue internacional; hay de todo: sueco, noruego, dinamarqués y hasta tártaro; lo que no se ve es que haya nada catalán; por lo menos, nada alto, nada fuerte, nada digno del país.

Todos los productos de la intelectualidad catalanista actual me parecen híbridos, sin el sello de la raza. Me dan la impresión de esas comidas de hotel y de sleeping-car, que todas se componen de una tortilla a la francesa y de un pollo desabrido envuelto en ensalada.

Aquí, en las cocinas de esos primates del intelectualismo catalanista, se huele a Emerson y a Carlyle, a Nietzsche y a Ruskin; lo que no aparece por ningún lado es el olor de la tierra. (Baroja, "Divagaciones acerca de Barcelona" 526)

Les argumentacions de Baroja no resulten excepcionals en el seu context — tret de l'explicitació del matís antisemita, veritablement una novetat en aquest sentit, perquè encara romania latent en l'article de Valera sobre Darío, tot i fer-ne esment. Potser hauria dit gairebé el mateix de qualsevol altra literatura europea; però no amb la mateixa virulència, ni sentint-ho com una despossessió o una pèrdua irreparable.

Aquesta seria la gran diferència entre la percepció espanyola dels dos modernismes, en un moment en què el camí específicament espanyol per al modernisme no solament sembla excepcional, sinó fins i tot contrari a la idea d'Espanya preconitzada per la generació d'escriptors dominant en aquell moment en el camp intelllectual de Madrid. Com assenyala Darío, les possibilitats d'una regeneració espanyola, a la qual encoratja i s'esforça per detectar elements que, 
per excepcionals que siguin, resultin remarcables, xoquen amb un entramat d'evidències reconeixibles en l'actitud generalitzada:

la casa de Lope cerrada a toda idea que no huela al aceite de las propias olivas, cuando la casa de Moliere y la casa de Shakespeare no se cierran; proteccionismo de las vejeces más ó menos gloriosas, a cuyo regimiento pertenece, o de amistades y simpatías personales, con daño de tres jóvenes modestos que han hecho un plausible esfuerzo; repudio de lo catalán, sin duda por las lecciones de arte y trabajo que Barcelona da; expulsión de lo bello francés a causa seguramente de que lo propio anda escaso; y, punto de mira principal, el dinero, el ansiado dinero, — cuya lindeza no nos atrevemos a contradecirle. ¿Cómo no? ¡Oh, no, buen señor! (Darío, España contemporánea, "Cyrano en casa de Lope", 52)

Aquests són els trets que constitueixen una unitat discursiva en la situació politicocultural espanyola del moment; les excepcions, però estan en un altre lloc. O es faran esperar. Contra aquests trets, Darío contrasta la perspectiva d'una Barcelona a la qual, tot i que no li dedica explícitament més que un capítol, retorna de manera recurrent, considerant-la capital d'un projecte modernitzador d'abast nacional, local i universal alhora, com una pedra de toc del camí que ell mateix havia iniciat, igual que Rusiñol, emmirallant-se en París, sense oblidar la realitat immediata de Barcelona o de Buenos Aires.

ANTONI MARTÍ MONTERDE Universitat de Barcelona

\section{NOTES}

1 Els principals treballs sobre España Contemporánea que podrien reflectir aquesta qüestió la consideren de manera més aviat succinta, quan no esbiaixada o inexistent. Andrés R. Quintián, en Cultura y literatura españolas en Rubén Darío (Madrid, Gredos, 1971) es limita a parlar de "La España catalana», a la qual dedica tot un capítol, però referint-se únicament a les lectures de literatura catalana de Darío, les seves relacions amistoses amb escriptors com Santiago Rusiñol, Alfons Maseras, Pompeu Gener i Gabriel Alomar, i en què fa un resum acrític de les visites a Barcelona i Mallorca, sense cap alusió a la qüestió política, ni la de signe catalanista ni la de caràcter social. Rocío Oviedo, en «Rubén Darío en el eje del 98: España entre la crónica y el viaje», (Compas de Letras, 7, desembre 1997, 181-94) només esmenta que "se debate el regionalismo", comparant breument els arguments de Darío sobre bascos i catalans en Espanya amb els de Miguel de Unamuno. En el pròleg a l'edició més recent del llibre, Antonio Vilanova es limita a afirmar que "su primera crónica, fechada el 1 de enero de 1899 , es a la vez una pintura magistral del bullicio callejero de la ciudad, una exposición inteligente y lúcida del problema del catalanismo político, y una descripción entusiasta del brillante papel que el movimiento modernista desempeña en la vida literaria y artística de la sociedad barcelonesa» (Antonio Vilanova, «Prólogo» a España contemporánea, Barcelona, Lumen, 
1987, 22), una apreciació en què el terme problema sembla paradoxalment tan inconscient com intencionat alhora. Adolfo Sotelo Vázquez, encara que sigui en un text molt breu, sí determina agudament i ponderada com les cròniques o memòries de les seves estades a Barcelona, de manera proporcional i indestriable, «amalgaman tres ingredientes: un animado cuadro del tejido urbano barcelonés, una sucinta e inteligente exposición del movimiento político, haciendo hincapié en el catalanismo, y una sintonía fervorosa con los quehaceres literarios y artísticos del modernisme, especialment con la brotherhood en torno a Rusiñol» (Sotelo Vázquez: Viajeros en Barcelona, 68). Per la seva banda, Fombona (La Europa necesaria) com a efecte de la seva pròpia perspectiva, invisibilitza la qüestió, eclipsada per la relació Amèrica-Espanya.

2 Són arguments que semblen donar la raó a Pascale Casanova en La République modiale des Lettres (París, Éditions du Seuil, 1999), qui ha aprofitat el pes del mateix meridià imaginat i sentit per Rusiñol - a qui no esmenta; sí a Rubén Darío, però de segona mà-, reformulat sota el concepte de capital simbòlic de Pierre Bourdieu, no sense certes trampes, per a situar en París el meridià de Greenwich de la seva proposta de República Mundial de les Lletres. Val a dir que a Casanova deixa escapar, segurament a banefici d'inventari, un detall cabdal: que una part importantíssima d'aquell capital simbòlic era artístic, pictòric, per ser més exacte, i ja no estrictament literari.

3 Ens limitem a les dades de l'època en què van viure Darío y Rusiñol, però el procés que comença aleshores continuarà fins que aquesta xifra, pel que fa al centre de la ciutat, es duplica en 1947, moment des del qual pràcticament no s'ha modificat, sempre al voltant dels tres milions d'habitants; és a dir, sense capacitat per a rebre més població i sense perdre'n, mentre el total del Gran Buenos Aires s'estenia fins els dotze o tretze milions que, des de fa més de mig segle, l'habiten en l'actualitat.

4 Vg. els respectius capítols sobre «La qüestió de les revistes. La caricatura», i «El cartel en España».

\section{REFERÈNCIES}

Leopoldo Alas “Clarín”. [ressenya de] "España contemporánea de Rubén Darío", La Publicidad, Barcelona, 7 d'abril de 1901; "Revista Mínima”, 1.

—. La Publicidad, Barcelona, 26 d'octubre de 1893; "Revista Mínima”, 1.

Baroja, Pío. "El problema catalán. La influencia judía” Madrid. El Mundo (15-noviembre1907): 1 .

—. "Divagaciones acerca de Barcelona”, Conferència pronunciada el 25 de març de 1910 a la Casa del Pueblo de Barcelona, Barcelona, El Progreso, 26 de març de 1910; rec. en Divagaciones Apasionadas, Obras. Completas, V, Madrid, Biblioteca Nueva, 1948.

Cacho Viu, Vicente. El nacionalismo catalán como factor de modernización. Barcelona: Quaderns Crema, 1998.

Darío, Rubén. "Los colores del estandarte", (La Nación, 27 de novembre de 1896), rec. en ¿Va a arder París?, ed. de Günther Schmigalle, Madrid: Veintisiete Letras, 2008. 62-68.

—. "Ricardo Palma”, (1890) Obras Completas de Rubén Darío I, Semblanzas, Madrid: Afrodisio Aguado, 1950. 15-29. 
—. "El periodista y su mérito literario" (s.d.), Obras Completas de Rubén Darío II, Crítica y ensayo, Madrid: Afrodisio Aguado, 1950. 880-81.

-. Prosas profanas, (1896) Obras Completas de Rubén Dario V, Poesía, Madrid: Afrodisio Aguado, 1950.

Darío, Rubén. España Contemporánea. París: Garnier Hermanos, 1901.

Fernández, Pura. "La editorial Garnier de París y la difusión del patrimonio bibliográfico en castellano en et siglo XIX”. Miscelánea Léxica en memoria de Conchita Serrano, Madrid: CSIC, 1999. 603-12.

Fombona, Jacinto. La Europa necesaria. Textos de viaje de la época modernista, Rosario: Beatriz Viterbo Editora, 2005.

Martí Monterde, Antoni. Poética del Café. Un espacio de la modernidad literaria europea. Barcelona: Anagrama, 2007.

Luis Monguió: "De la Problemática del Modernismo: La Crítica y el 'Cosmopolitismo'”. Revista Iberoamericana XXVIII 53 (1962): 225-42.

Pardo Bazán, Emilia. "Embajadas. Un libro argentino. Núñez de Arce”, La Ilustración artística 1005 (Barcelona, 1-abril-1901). Recogido en apéndice, con diferente título (“Un libro de Rubén Darío sobre España”) en: Rubén Darío. España Contemporánea. Barcelona: Lumen, 1987. 313-16.

Oviedo, Rocío. "Rubén Darío en el eje del 98: España entre la crónica y el viaje". Compás de Letras 7 (1997): 181-94.

Quintián, Andrés R. Cultura y literatura españolas en Rubén Darío. Madrid: Gredos, 1971.

Rama, Ángel. La ciudad letrada, Madrid: Fineo, (1984) 2009.

-. Rubén Darío y el Modernismo. Caracas-Barcelona: Alfadil, 1985.

Resina, Joan Ramon. La vocació de modernitat de Barcelona. Auge i declivi d'una imatge urbana, Barcelona: Galàxia Gutenberg, 2008.

Rusiñol, Santiago. Desde el Molino. París: Garnier Hermanos, 1901.

Sotelo Vázquez, Adolfo. Viajeros en Barcelona. Barcelona: Planeta, 2005.

Valera, Juan. Cartas americanas. Madrid: Fuentes y Capdeville, 1889.

Vilanova, Antonio. "Prólogo" a España contemporánea. Barcelona: Lumen, 1987. 9-26. 